\title{
THE EXISTENCE OF INDONESIAN LANGUAGE AS A NATIONAL IDENTITY IN THE MILLENNIAL ERA
}

\author{
Rizky Ayu Khoirun Nisa ${ }^{1}$, Moses Glorino Rumambo Pandin ${ }^{2}$ \\ ${ }^{1}$ Indonesian Language and Literature Study Program, Faculty of Cultural Sciences, Airlangga \\ University \\ Email : $\underline{\text { rizky.ayu.khoirun-2020@ fib.unair.ac.id }}{ }^{1}$ \\ ${ }^{2}$ Department of English Language and Literature, Faculty of Humanities, Universitas \\ Airlangga \\ Email : moses.glorino@fib.unair.ac.id $^{2}$
}

\begin{abstract}
Indonesia is a country that has a diversity of languages. The many ethnic groups and cultures are capital for Indonesia to foster a sense of unity and strengthen national identity through the use of the Indonesian language. In the current millennial era, Indonesian is rarely used by some people, especially young people. This article tries to provide answers to the questions regarding (1) What are the factors that cause the existence of the Indonesian language to be marginalized? and (2) What efforts should be made to strengthen the existence of the Indonesian language again? Writing the data for this article uses a qualitative method of literature study with a literature review of journals for the years 2019-2021. The results found through reading journals indicate that the factor that causes the marginalization of the existence of Indonesian is the influence of foreign languages and slang which are now more often used. It takes a strong commitment and good self-awareness for the Indonesian people to be able to restore the existence of the Indonesian language.
\end{abstract}

\section{Keywords: Existence, Indonesian language, national identity}

\section{INTRODUCTION}

Language is an important thing in human life. Language serves as a communication tool between humans to understand each other. In addition, language also functions as the identity of a particular country or group of people. Indonesia itself has a quite unique identity that is able to distinguish it from other nations. The identities formed through this long historical process should not be lost or taken away. The youth as the next generation of the nation have an obligation to maintain and preserve it. Especially in the use of Indonesian which every year looks increasingly sad. Teenagers today more often speak using a foreign language, 
slang, or a strange language that only a group of them understand. This makes the existence of the Indonesian language begin to be marginalized and of course automatically becomes the seed for the formation of an identity crisis for the Indonesian nation.

On October 28, 1928, to be precise, at the Youth Pledge, Indonesian was inaugurated as the language of unity to facilitate communication between ethnic groups. This inauguration is a manifestation of the actualization of unity as the identity of the Indonesian nation which is widely mentioned through the motto, "different but still one". As a nation built on the basis of ethnic and cultural diversity, the decision to make Indonesian the national language in the Republic of Indonesia is not an easy matter to decide (Bulan, 2019). This is because the people who at that time communicated using their respective regional languages, then it was decided to adapt to using Indonesian which incidentally has its roots in the Malay language. The choice of Malay as the basic material for the creation of the Indonesian language is because the Malay language system is simple, has no levels of pronunciation. In contrast to the Javanese language which has levels such as krama inggil, krama madya, ngoko alus, and ngoko innocent. In addition, the Indonesian language grew and developed from the Malay language which has been used since ancient times as a language of communication (lingua franca) not only in the Archipelago, but also in almost all of Southeast Asia (Arisandy et al., 2019).

As a national language, Indonesian serves as a symbol of national pride, national identity, a liaison media between citizens, between regions and between cultures, as well as a unifying media for tribes, cultures and languages in the archipelago (Bulan, 2019). In this case, the Indonesian language has a broad coverage, namely all parts of the territory of Indonesia. As a symbol of national pride, it can be interpreted that the Indonesian language is a form of communication tool created by the Indonesian people themselves. Rooted in the Malay language which was developed, it has succeeded in forming a language which now functions as a unifying language of communication for all Indonesian people.

The purpose of writing this article is to provide information to readers that the identity of a country can be threatened at any time, either threatened with extinction or threatened with being stolen by irresponsible parties. Therefore, every citizen is obliged to maintain and preserve what is owned by his nation so that the worst possibilities such as an identity crisis do not occur. The next goal is to warn the Indonesian people, especially millennial teenagers, to be able to reaffirm the existence of Indonesian language among other languages because 
Indonesian is a very important national identity. In addition, this article was written to develop research that has been done previously, as well as to become a reference for similar research in the future. The future of a country without an identity will only run without direction. Just like humans who always try to be like other people, but in the end it causes suffering for themselves.

Based on the introduction that the author has conveyed above, two questions can be made as follows (1) What are the factors that cause the existence of the Indonesian language to be marginalized? and (2) What efforts should be made to strengthen the existence of the Indonesian language again? Thus, it is hoped that this article can provide a good explanation of these two questions, and can provide insight to the citizens of the nation to better understand the following: national identity as a national character; source of Indonesian national identity; and the condition of the Indonesian national identity. At the practical level, furthermore, it is hoped that the citizens of the nation can apply an understanding of the national identity of the Indonesian nation and its implementation in organizing the life of society, nation and state (Hendrizal, 2020).

\section{METHODS}

The data collection in this article uses a qualitative method of literature study in the form of literature reviews from several journals related to the Indonesian language and national identity. Qualitative research is an inquiry strategy that emphasizes the search for meaning, understanding, concepts, characteristics, symptoms, symbols and descriptions of a phenomenon, focused and multi-method, natural and holistic, prioritizing quality, using several methods, and presented in a narrative (Shidiq \& Choiri) , 2019). Literature review is carried out by collecting various journals and reading books published in 2019-2021. These various journals and reading books were obtained from several reference sources such as Google Scholar, Garuda Research and Technology, iPusnas, etc. The reading of the journals was carried out for two weeks and then followed by analyzing the data for one week so that the total time used for writing this article was estimated to be one month.

The object of this research is the Indonesian people, especially millennial teenagers, because nowadays many millennial teenagers tend to use other languages outside Indonesian, especially in the realm of social media. The focus of this article refers to the analysis of phenomena that exist in people's lives, both real and virtual. In writing a literature review, several stages are needed, namely (1) determining the topic to be discussed, (2) searching for 
relevant sources, (3) determining strategy and development, (4) reviewing each journal and book, (5) writing a review, (6) applying the results of the literature to the study to be conducted.

\section{DATA FINDINGS}

The majority of Indonesia's population is bilingual. When viewed from the use of the language, it can be said that someone who is an Indonesian national will have at least two identities, their ethnic identity and national identity. For this reason, the use of Indonesian as the national language certainly plays a major role in maintaining the national identity of the Indonesian nation (Bulan, 2019). National identity is essentially a manifestation of cultural values that grow and develop in aspects of a nation's life with characteristics that are different from other nations in their lives. To determine the national identity of the State of Indonesia, it is very difficult if it is only described based on physical characteristics. Bearing in mind that the Indonesian nation consists of various elements of race, culture, religion, and character, which from the beginning did have a difference. Thus, to know the national identity and personality of the Indonesian nation is not enough to only be understood statically but must also be understood in a dynamic context (Antari, 2019).

Historically, Indonesia's national identity was marked when the awareness of the Indonesian people emerged as a nation that was being colonized by foreign nations in 1908 which was then known as the period of national awakening (the nation). The Indonesian people are starting to realize their identity as human beings who are not natural because they are in a condition of being colonized. At that time, awareness emerged to form a nation. This awareness arises because of the influence of educational outcomes received as a result of ethical politics. In other words, the element of education is very important for the formation of culture and awareness of nationality as a national identity. As a symbol of national identity, the Indonesian language must continue to be developed so that it can still fulfill its function as a modern means of communication in various fields of life. In addition, the quality of its use must continue to be improved so that the Indonesian language can be an effective and efficient means of communication for various purposes. Indonesian language can have its own identity if people are willing to use, learn, foster and develop in such a way that the Indonesian language itself is pure without a mixture of other language elements, especially foreign languages (Antari, 2019).

Regarding the current Indonesian language, there is no strong commitment from its speakers to put Indonesian in the most important place. In fact, language behavior by 
Indonesian speakers tends to be negative. This is evidenced by several facts that the existence of the Indonesian language is threatened by the use of foreign languages. Seen in several government agencies, private sector, and certain places using foreign languages without juxtaposing it with Indonesian, especially regional languages (Anto et al., 2019). Nowadays, the influence of foreign languages is prominent in Indonesian. There is a tendency that people prefer to prioritize English over Indonesian. In a sense, people are more proud to use English to express certain things or to name something even though it can actually be stated in Indonesian. The reason they put forward is that England has a higher prestige value in addition to commercial value. Writing the names of shops, hotels, companies, housing, tourist attraction locations, or the use of foreign terms in Indonesian sentences is evidence that can be found everyday (Devianty, 2020).

The use of English in several public places has become the culture of the millennial generation. This is what causes the erosion of the authority of the Indonesian language. Slowly, but surely, foreign languages, especially English, will become the pride of the Indonesian people. Unfavorable attitudes towards the Indonesian language have hit various groups of people in Indonesia, both the lower, middle, and upper (intellectual) circles (Anto et al., 2019). Today's students feel they will be more than other students when speaking in a foreign language. They think that if they use Indonesian, they will seem ordinary, so that they deify foreign languages as their daily language. Actually, the factor that causes this is not solely from the youth themselves but their educational demands to get used to speaking in foreign languages while in the forum so that it is carried over to their daily lives and in their environment using these foreign languages. On the other hand, technological demands also make them carried away by this foreign language. They often struggle with technology, and the language used by technology itself generally uses a foreign language (Ibda, 2020).

It is a must regarding the ability to use good and correct Indonesian. As an Indonesian citizen, you should be able to use good and correct Indonesian regardless of what generation the person is from. This is a must because in its position Indonesian as the language of national pride, national identity and a unifying tool of the nation. Even the position of the Indonesian language is explained in Article 36 of the 1945 Constitution regarding the position of Indonesian as the official state language, an introduction to education, a national level liaison tool, and a tool for developing culture and science and technology. Based on the position of the Indonesian language, automatically Indonesian must be used in formal and non-formal 
activities. But in reality what is happening now is that the use of Indonesian among the people has been mixed with slang (Azizah, 2019).

A phenomenon that is currently hitting teenagers in Indonesia, they use words that only their group knows which they call slang. The sophistication of social media technology is currently very influential on the spread of slang in Indonesia. They will more quickly know today's slang. They think that if they can't speak slang, then they are not up to date. Thus, the Indonesian language will be increasingly threatened if young people who are actually the nation's successors are more proud to speak slang than to speak good Indonesian (Antari, 2019).

Behind the crisis of the existence of the Indonesian language, the government and society have actually made efforts so that the Indonesian language is not threatened by its existence. In terms of education, the government makes Indonesian a compulsory subject in schools. In addition, there is also language training and language socialization. Indonesian language development is carried out in various ways, three of which are Indonesian language learning, Indonesian correctionalization, and utilization of internal language potential. In all types and levels of education, from elementary school (SD) to university (PT), there are Indonesian language subjects and/or general Indonesian subjects (MKU) with a weight of 2-3 credits. Meanwhile, the correction of the Indonesian language is carried out by the Language Agency and its technical implementing units (UPT) in the regions, such as the Language Center and the Language Office through the publication of infographics, such as "Did You Know?", "Spelling Today", and "Kata We Are This Week" (Sudaryanto et al., 2019). Then, the utilization of the internal potential of language is to increase the flexibility and intellectualization of the structure and system of language, and at the same time stimulate creativity in the use of language. Stability improvements are still being carried out by publishing spelling guidelines, term guidelines, dictionaries, grammar books, and textbooks (Widowati, 2019). Through these methods, it proves that not all people are indifferent to the Indonesian language, but they still have a sense of caring for the identity of the nation.

\section{DISCUSSION}

From the data from reading some literature, it shows that the factor that causes the marginalization of the existence of the Indonesian language is the influence of foreign languages and slang which are now widely used by millennials in Indonesia. In addition, the lack of public pride in their own nation and the demands to advance in the international arena 
are also strong factors of this problem. The marginalization of the existence of the Indonesian language needs to get the right solution so that in the future it can return to its essence. The language that has been taught by parents since childhood, learned in schools, and made the easiest choice when communicating must always be maintained well even though it is in competition with other languages.

Language can die because of the pressures of another language that lives with it or maybe another language that lives under it. The advantages in roles and functions will determine whether other languages are still allowed to move and wriggle or even close the opportunity and completely eliminate their roles and functions by a stronger language. Indonesian is currently competing with foreign languages for the strongest position in its own nation, namely Indonesia. However, Indonesian seems invisible to be used and even discarded by its owner so that it is clear that Indonesian has a very weak role and function in society (Ibda, 2020). Referring to the roles and functions, Indonesian language does have an important role in people's lives, but it cannot be denied that foreign languages are no less important, especially now that globalization is everything for life. Starting from technology, communication, information and news, education, health, transportation, etc. have close ties with foreign countries. Until finally, demanding the Indonesian people to focus more on learning foreign languages.

In this global era, the identity of a nation is very important to maintain so that our nation can still show its existence among other nations in the world (Antari, 2019). With many people's ambitions to go international, they tend to prefer to study foreign languages rather than Indonesian. In fact, this is a golden opportunity for millennial teenagers to introduce their own language to foreign audiences. This reminds me of the Indonesian president, Joko Widodo. During his overseas visits, he proudly gave speeches in front of representatives of other countries using Indonesian. Although the majority of the audience did not understand the meaning of what Mr. Joko Widodo conveyed, it did not become an obstacle to the continuity of the meeting. An example like this deserves to be imitated and applied in real terms, instead of being responded to by pretending to close your ears and close your eyes or even blaspheme outright.

The creativity of millennial youth today has no limits. Covers all fields including language. In a youth association, judging from the conversations carried out, it is often found 
using slang. The slang here is generally a form of adaptation of the Indonesian language that is slurred. Not only in youth associations, this can be found on social media. A simple example, when someone with their friends reply to each other in the comments column of a post, and uniquely the conversation that is said to tend to be strange and only understood by them.

Continuing on an irony that hit the Indonesian language. In this era of progress, many schools and universities require their students to pass a foreign language test as a condition for accepting new students. This looks strange, because these students want to take an education which is actually located in Indonesia and managed by the Indonesian government, but in fact it is not the Indonesian language test that is an indicator of acceptance. It is even more ironic to see that many parents who send their children to prestigious schools feel panic if their children cannot speak foreign languages instead of speaking Indonesian. They flocked to teach their children to be good at foreign languages. Looks ironic doesn't it? But in fact there are still many people who do not realize it all.

Every disease must have a cure as well as every problem must have a solution. Indonesian people need to have a sense of nationalism towards their nation because nationalism is able to revive all the elements that make up the identity of a nation. In addition, education in Indonesia also needs to be used as a support to improve the quality of people's knowledge of the Indonesian language. Not all Indonesian citizens understand what the meaning of good and correct Indonesian is. Indeed, it is not necessarily true that Indonesian is good and good Indonesian is correct. Good Indonesian is a language that is appropriate to the situation and conditions and is effective in conveying meaning to the interlocutor. While the correct Indonesian is Indonesian which is in accordance with the rules of the standard language (Azizah, 2019).

In terms of education, learning Indonesian in higher education must be contextual, in addition to being oriented towards understanding the language and its functions, students must be led to master technology, data presentation and the quality of human resources. This can be applied in language skills conceptualized through Indonesian language learning (Ibda, 2020). To be more interesting, learning Indonesian can be done in several ways, namely, first, motion audio-visual media, for example: films and animations that are presented through television or other equipment. The second media, silent visual media, for example: slides, printed pages, and photos. Third, semi-motion audio, for example: writing that can move and sound, generally 
from modified power points. Fourth, audio media, for example: telephone, audio tape, and radio. Fifth, print media, for example: modules and books. Sixth, the environment as a learning medium (Anwar et al., 2020).

Getting used to always using Indonesian in everyday life is very important. The slightest thing will definitely have a lot of influence in the next life such as talking to peers, writing captions on photo posts, congratulating, shopping, ordering food, etc. things like this will slowly become a habit so that when something new is entered into the habit, you will automatically respond and think again whether this new thing has the role it needs or not. It requires a strong commitment from speakers of the language related to mastering a foreign language without having to put aside the original language (Anto et al., 2019). The identity of the Indonesian nation is the result of an agreement with the nation about the future based on past experiences. National identity must always undergo a process of coaching through education for the sake of forming solidarity and improving fate in the future (Antari, 2019).

It should be emphasized in this matter, the author is not at all anti-foreign language, slang and other languages outside Indonesian. The author only tries to provide information regarding the existence of the Indonesian language and the factors that influence it along with solutions to the problem. The author realizes that all languages are always important in human life. Language certainly has its own role and function depending on the place and time it is used. Learning various languages also brings many benefits to every human being. Besides being able to improve brain performance, train self-skills, facilitate communication, and accelerate understanding of the material. It's just that we as language users must be smart to use it, understand its limitations, be disciplined in measuring its use so that language will continue to develop, maintain its existence and be useful in its place.

\section{CONCLUSION}

Existence signifies the existence of everything that exists on earth. With a strong existence, the more it is believed that something is true. Likewise with the existence of the Indonesian language, the more people who use the Indonesian language and accompanied by sufficient intensity, automatically the existence of the Indonesian nation is also getting stronger in the eyes of other countries. Globalization which is now a major element in people's lives should be put to good use. Moreover, the current generation has the ability to use digital access. With a sense of nationalism that is embedded in the soul, education and development of the 
Indonesian language that continues to grow, habits in the Indonesian language, and other efforts. So, it is certain that the existence of the Indonesian language will continue to be sustainable for the next generations. It should be remembered that the Indonesian language is a reflection of national identity that must be maintained and used properly and correctly. The younger generation should be able to control themselves so that they are not influenced by foreign cultures and result in the loss of national identity.

Indonesian language education would be better not only done theoretically, but also practically. It's as simple as communicating with family at home using Indonesian every day, writing, praying, singing, etc. In addition, the Indonesian language education system also needs to be improved, especially in terms of the level of education that requires passing a foreign language test as a guarantee of one's success in pursuing education. We all must be able to make the best use of Indonesian language education because then our national identity will always be maintained through language.

\section{Rizky Ayu Khoirun Nisa ${ }^{1}$, Moses Glorino Rumambo Pandin ${ }^{2}$ \\ Airlangga University}

\section{REFERENCE}

Antari, L. (2019). Indonesian Language as Indonesian National Identity. Stylistics, 8(1), 92108. http://ejournal.unibba.ac.id/index.php/jisipol/article/view/115

Anto, P., Hilaliyah, H., \& Akbar, T. (2019). Prioritizing Indonesian: An Applicative Step. El Banar, 02(1), 17-24.

Anwar, M., Pramujiono, A., SB, A., \& Ardianti, M. (2020). Indonesian Language Learning for Millennial Generation. PHONEMA Scientific Journal, 3(1), 58-67.

Arisandy, D., Rizkika, D. P., \& Astika, T. D. (2019). The Existence of Indonesian in the Millennial Generation in the Industrial Era 4.0. Indonesian Language and Literature Education, 3(2), 247-251. garuda.ristekbrin.go.id

Azizah, A. R. (2019). The Use of Indonesian and Slang among Adolescents. Journal of Scripts: Journal of Indonesian Language and Literature Learning, 5(2), 33-39. 
Bulan, D. R. (2019). Indonesian as the National Identity of the Indonesian Nation. JISIPOL Journal, 3(2), 23-29. http://ejournal.unibba.ac.id/index.php/jisipol/article/view/115

Devianty, R. (2020). The Existence of Indonesian during the Pandemic Period. Nizhamiyah, 10(2), 27-41.

Hendrizal. (2020). Reviewing the Latest Indonesian National Identity. Journal of Civics \& Law, 15(1), 1-21.

Ibda, H. (2020). Learning Indonesian with New Literacy Insights in Higher Education in Responding to the Challenges of the Industrial Revolution Era 4.0. Jalalanguage, 15(1), 48-64. https://doi.org/10.36567/jalalanguage.v15i1.227

Shidiq, U., \& Choiri, M. (2019). Qualitative Research Methods in the Field of Education. In Journal of Chemical Information and Modeling (Vol. 53, Issue 9). http://repository.iainponorogo.ac.id/484/1/QUALITATIVE RESEARCH METHODS IN THE FIELD OF EDUCATION.pdf

Sudaryanto, S., Hermanto, H., \& Gustiani, E. I. (2019). Social Media as a Means of Fostering Indonesian Language in the Digital Age. Journal of Languages, 8(4), 61-74. https://jurnal.unimed.ac.id/2012/index.php/kjb/article/view/16005

Widowati, D. F. (2019). The Existence of Indonesian Language in Supporting Science. Languages, 8, 1-8. 